\title{
Using Mouse Genetics to Understand Infectious Disease Pathogenesis
}

\author{
William F. Dietrich ${ }^{1}$ \\ Howard Hughes Medical Institute/Harvard Medical School, Department of Genetics, Boston, Massachusetts 02115, USA
}

The study of mouse and human genetic variation in infectious disease susceptibility (for review, see Malo and Skamene 1994; Hill 1998) should help to improve our knowledge of disease mechanisms by facilitating the identification of critical host proteins that modulate the infection process. Focusing on differences in disease susceptibility in humans will contribute to making progress in this field, but it is also possible to use mouse genetics to identify genes whose human orthologs are likely to affect the outcome of infections in man. It is impossible to adequately review all of the work that has been done to study the genetics of infectious disease susceptibility and pathogenesis. Therefore, I will discuss studies of two different bacterial infections. Although this is not a comprehensive approach, the examples help to illustrate my view that progress in understanding host susceptibility to infection will be facilitated by genetic studies of mouse models of infectious disease.

\section{Susceptibility to Mycobacterial Infections}

There are wide variations in susceptibility to mycobacterial disease in human and mouse populations (Bellamy 1998). Several mutations with profound effects on human mycobacterial susceptibility have been identified through the study of rare patients who presented with diseases caused by weakly pathogenic $M y$ cobacterium spp. (Altare et al. 1998; Jouanguy et al. $1999 a, b)$. In addition, it is likely that future genomewide screens in humans will solidify identification of novel genes involved in susceptibility to mycobacteria (Bellamy et al. 2000). However, mouse genetics offers a valuable complementary approach.

The study of mycobacterial pathogenesis and host defense has been powerfully influenced by the positional cloning of a mouse gene that affects susceptibility to diverse intracellular pathogens, including several (but not all) Mycobacterium spp., as well as Salmonella typhimurium and visceral Leishmaniasis pathogens (Vidal et al. 1993, 1995; North et al. 1999; Gruenheid and Gros 2000). This gene is currently called by the rather esoteric name of Solute Carrier Family 11, member 1 (Slc11a1), although the literature contains references to it by many other names, such as $B c g$, Lsh, Ity,

'E-MAIL dietrich@rascal.med.harvard.edu; FAX (617) 432-3993. Article and publication are at www.genome.org/cgi/doi/10.1101/ gr.173101.
Nramp, and Nramp1. Slc11a1 is exclusively expressed in phagolysosomes within mononuclear phagocyte cells, where it acts to restrict growth of intracellular organisms (Vidal et al. 1993, 1996; Govoni et al. 1997; Gruenheid et al. 1997). By analogy to its mammalian homolog Slc11a2 (also known as Nramp2, DMT1, and DCT1), Slc11a1 has been postulated to be a unidirectional transporter of divalent metal ions (Fleming et al. 1997; Gunshin et al. 1997). It may act by depleting the metal ion content of phagosomes containing intracellular pathogens, depriving them of iron, manganese, or other metals required for their proliferation. This model is consistent with the observation that wildtype Slc11a1 appears to act by attenuating pathogen replication, rather than by promoting killing (Stach et al. 1984).

Amazingly, Slc11a1 is a member of a large family of metal ion-transporting protein genes that are contained in the genomes of organisms from bacteria to mammals (D'Souza et al. 1999; Curie et al. 2000; Kehres et al. 2000; Makui et al. 2000; Thomine et al. 2000). This fact raises the possibility that some intracellular pathogens and their host cells undergo a molecular struggle of orthologous proteins, with each attempting to gain an advantage through efficient sequestration of nutrients critical for the intracellular survival of the infecting microbe (for review, see Gruenheid and Gros 2000).

It is not yet clear whether Slc11a1 is involved in human resistance to mycobacterial pathogens. A few published case-control association and genetic linkage studies have provided evidence that the chromosomal region surrounding SLC11A1 influences human susceptibility to mycobacterial disease, although this influence is not observed in all populations (Shaw et al. 1997; Abel et al. 1998; Bellamy et al. 1998, 2000; Bellamy 2000; Greenwood et al. 2000). Although this needs to be investigated further, it is clear that the effect of SLC11A1, should there be one, is either strongly influenced by alleles of other susceptibility genes, or is somewhat weak and variable across populations. Nevertheless, despite the apparent infrequent occurrence of powerful functional polymorphism in SLC11A1, it is likely that its molecular action is identical to that of the mouse ortholog. As such, this gene (and its microbial homologs) is a viable starting point for research into the design of new therapeutic inter- 
ventions to fight disease caused by intracellular pathogens.

Slc11a1 is not going to be the only mycobacteria susceptibility gene identified using mouse genetics. Recent work has identified two quantitative trait loci (QTL) on chromosomes 3 and 9 that have sex-specific effects on $M$. tuberculosis infection-induced weight loss (Lavebratt et al. 1999). In addition, a locus on chromosome 1 (distal to Slc11a1) that influences M. tuberculosis infection-induced mortality has been reported (Kramnik et al. 2000). The ultimate positional cloning of these mouse genes will undoubtedly provide other avenues of research into infectious disease mechanisms, as was seen in the case of Slc11a1.

There are additional reasons to assert that studies in the mouse will contribute even more to the understanding of genetic differences in susceptibility to mycobacteria. The ability to make mutations in any mouse gene using homologous recombination offers the opportunity to test the involvement of specific host defense mechanisms in infectious diseases. Many mouse knockouts involving known immune system genes have been found to influence susceptibility to mycobacterial pathogens (e.g., see, Flynn et al. 1992, 1993, 1995; Cooper et al. 1993, 1997, 2000; Dalton et al. 1993; MacMicking et al. 1997; Ehlers et al. 1999, 2000; Sugawara et al. 1999). In some cases, these mouse models provide an opportunity to conduct detailed studies of mutations in mouse immune system pathways (Cooper et al. 1993, 1997; Dalton et al. 1993; Flynn et al. 1993) whose human counterparts are known to affect mycobacterial pathogenesis (for review, see Jouanguy et al. 1999a).

\section{Susceptibility to Legionnaire's Disease}

Legionella pneumophila is a significant community- and hospital-acquired pathogen that can cause either a severe pneumonia called Legionnaire's Disease or a milder febrile illness called Pontiac Fever (Bernstein and Locksley 1991). The estimates of the overall incidence of Legionnaire's Disease vary, but some studies suggest that Legionella infection may account for as many as 5\%-10\% of community-acquired pneumonia cases (Fang et al. 1990). The incidence of mildly symptomatic or asymptomatic Legionella infection in human populations is unknown, although a few studies have suggested high rates of antibody positivity in certain populations (Sampson 1988; Bernstein and Locksley 1991). The reason for this apparent variability in human disease susceptibility is not known. Possible explanations include differences in the inoculation route or size, differences in the genetic background of the host, or genetic differences in pathogen virulence.

Legionella is a facultative intracellular parasite that exploits a poorly understood process within mammalian macrophage cells. Legionella's ability to cause dis- ease is intimately linked to its ability to replicate inside of an unusual rough endoplasmic reticulum-bounded endocytic compartment (for review, see Ciancotto et al. 1989; Marra and Shuman 1992). Study of avirulent bacterial mutants has revealed that Legionella's intracellular survival is likely to be dependent on bacterial secretion of a nucleic acid or protein into the host cell via a type IV secretion apparatus (Winans et al. 1996). This macromolecular transfer, which occurs within minutes of the phagocytosis event, may alter the endocytic physiology of the host cell, preventing fusion of the Legionella-containing phagosome with lysosomes (for review, see Vogel and Isberg 1999).

Determining how Legionella exploits normal cellular processes during infection will be informative in terms of understanding disease caused by Legionella and in identifying macrophage defense functions that are also important in other infectious diseases. Fortunately, critical observations were made several years ago that have allowed the use of mouse genetics to study this problem. Cultured macrophages from different inbred mouse strains differ in their ability to support intracellular Legionella replication (Yamamoto et al. 1988, 1992). This difference in phenotype (in at least one permissive/nonpermissive strain combination) segregates in a Mendelian fashion (Yamamoto et al. 1991; Yoshida et al. 1991). Two groups independently have established that the gene responsible for the macrophage permissiveness difference (called Lgn1) maps to mouse chromosome 13 (Beckers et al. 1995; Dietrich et al. 1995).

Detailed molecular characterization of the mouse Lgn1 interval has demonstrated that it consists of a series of $80-100 \mathrm{~kb}$ direct repeats, each of which contains a paralogous member of the Naip gene family (Scharf et al. 1996) (Fig. 1). The Naip genes, whose human orthologs (NAIPs) are also organized in a repetitive array, were described originally as candidate genes for spinal muscular atrophy (Roy et al. 1995). In addition, the Naip/NAIP genes are members of a larger gene superfamily of BIR domain-containing proteins (BIRPs) (Miller 1999).

The defining structural feature of the BIRP family is a zinc coordination motif that can mediate proteinprotein interactions (the BIR domain) (Deveraux and Reed 1999; Miller 1999). Some members of the BIRP family can alter cellular susceptibility to apoptosis; this ability is dependent on the BIR domains (Deveraux and Reed 1999; Miller 1999). However, other members of the BIRP family appear to participate in chromosome condensation, alignment, and segregation during mitosis and meiosis (Speliotes et al. 2000).

Although some of the mouse and human Naip/ NAIP proteins have been implicated in cell death pathways (Liston et al. 1996; Holcik et al. 2000; Mercer et al. 2000), it is not clear that this is their true physiologic 


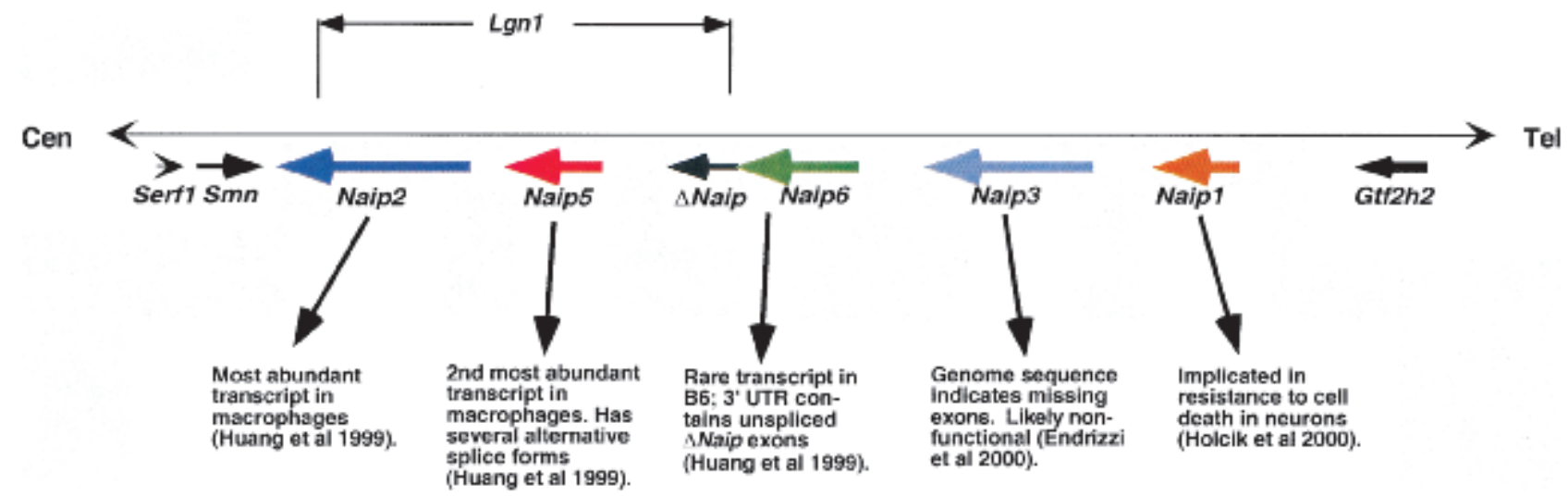

Figure 1 Map of the Naip gene family array in C57BL/6]. The horizontal line depicts the chromosome and the named arrows beneath the lines indicate the relative position and direction of transcription of the C57BL/6] mouse Naip gene paralogs. In addition, some flanking

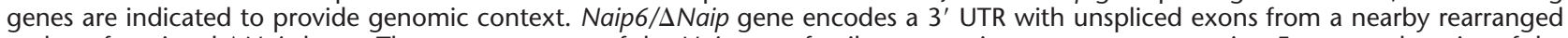
and nonfunctional $\Delta$ Naip locus. The exact structure of the Naip gene family array varies among mouse strains. For example, mice of the 129 background have an expanded central portion of the Naip array that contains two additional close relatives of the Naip6/DNaip gene locus (Endrizzi et al. 2000; Growney and Dietrich 2000). Interestingly, the human orthologous region also contains repeats of NAIP gene sequences, although the map is uncertain because of considerable interhaplotype variability in structure (for review, see Growney et al. 2000). The genetic interval for Lgn1, which contains only Naip2, Naip5, and the 3' UTR of Naip6/DNaip, is indicated above the chromosome. Arrows below each Naip symbol point to some relevant information about each gene.

role. Furthermore, the predicted proteins encoded by the mouse Naip genes are only $85 \%$ identical, with many nonconservative substitutions throughout, making it possible that the mouse Naip genes encode a diversity of functions (Huang et al. 1999). Recently, the critical interval for $L g n 1$ was narrowed to contain the entirety of Naip5 and portions of two other Naip genes (Naip2 and Naip6) (Growney and Dietrich 2000). Because other transcriptionally active Naip paralogs exist outside this critical interval, it appears that the Naip proteins do not have entirely redundant molecular functions.

We will soon learn which of the Naip genes is responsible for the Lgn1 phenotype and whether structural variation in the human NAIP locus (Lefebvre et al. 1995; Roy et al. 1995; Growney et al. 2000) can influence susceptibility to Legionella. It will be important to determine whether Naip's effect on Legionella permissiveness involves a differential apoptotic response of the infected cell (Gao and Abu Kwaik 1999; Weinrauch and Zychlinsky 1999) or another, as yet unknown, Naip function.

In this vein, it is tempting to speculate that the Naip gene responsible for the Lgn1 phenotype may physically interact (via its BIR domain) with virulence factor proteins that are secreted by Legionella into the host cell. A recent report documenting increased expression of mouse Naip upon phagocytosis of bacteria or inert particles (Diez et al. 2000) can be viewed in light of a possible role for Naip in regulating endocytic traffic. If this hypothesis is true, Legionella may interfere with Naip activity to gain entry into a priveleged intracellular compartment.

\section{Concluding Remarks}

Even while investigators are swimming in genomic sequence information, the use of genetics to make unexpected connections between genes and phenotypes will remain a staple of gene function discovery. Because infections are a major cause of human morbidity and mortality (World Health Report 1999), I argue that susceptibility to infectious disease is among the most important phenotypes to study thoroughly. Certainly, a broader understanding of genes that influence host defense will translate into a greater likelihood of identifying cellular functions that can be manipulated for therapeutic goals.

Undoubtedly, human genetic methods will continue to impact our understanding of infectious disease susceptibility (Abel and Dessein 1998). In particular, the generation of high-density single nucleotide polymorphism (SNP) maps of the human genome may allow population-based searches for polymorphisms that are in linkage disequilibrium with disease status (Risch and Merikangas 1996; Kruglyak 1999; SNP Consortium). However, genetic analysis of phenotypic differences in mouse models of infectious disease represents a very strong complement to human genetic studies.

In this article, I have presented a few examples of how mouse genetics has begun to contribute to our understanding of infectious pathogenesis. Table 1 is a more comprehensive (though probably incomplete) synopsis of published mouse genetic studies of infectious disease that were not discussed in this article. A casual review of this table suggests that the genetic analysis of mouse models of infec- 
Table 1. Mouse Genetic Models of Infectious Disease Susceptibility

\begin{tabular}{|c|c|c|c|}
\hline & Disease & Position/Gene ${ }^{a}$ & References \\
\hline $\begin{array}{l}\text { Genetic variants in } \\
\text { susceptibility }\end{array}$ & $\begin{array}{l}\text { Chagas Disease } \\
\text { Tularemia }\end{array}$ & $\begin{array}{l}\text { N.D. } \\
\text { N.D. }\end{array}$ & $\begin{array}{l}\text { Trischmann } 1984 \\
\text { Anthony et al. } 1988\end{array}$ \\
\hline $\begin{array}{l}\text { Documented genetic } \\
\text { linkages }\end{array}$ & $\begin{array}{l}\text { Anthrax } \\
\text { Mouse Cytomegalovirus } \\
\text { Leishmaniasis }^{\mathrm{b}} \\
\text { Listeriosis }^{\mathrm{c}} \\
\text { Malaria }^{\mathrm{d}} \\
\text { Salmonellosis }^{\mathrm{b}} \\
\text { Sleeping Sickness }\end{array}$ & $\begin{array}{l}\text { Chr. } 11 \\
\text { Chr. } 6 \\
\text { Multiple QTL } \\
\text { Multiple QTL } \\
\text { Multiple QTL } \\
\text { Multiple QTL } \\
\text { Multiple QTL }\end{array}$ & $\begin{array}{l}\text { Roberts et al. } 1998 \\
\text { Scalzo et al. } 1990 \\
\text { Beebe et al. 1997; Roberts et al. 1997, 1999; } \\
\quad \text { Lipoldova et al. } 2000 \\
\text { Boyartchuk et al. (in press) } \\
\text { Wunderlich et al. 1988; Foote et al. 1997; } \\
\quad \text { Fortin et al. 1997; Burt et al. 1999 } \\
\text { Sebastiani et al. 1998 } \\
\text { Kemp et al. } 1997\end{array}$ \\
\hline Genes identified & $\begin{array}{l}\text { Typhus } \\
\text { Gram Negative Septic Shock } \\
\text { Influenza }\end{array}$ & $\begin{array}{l}\text { Etal } \\
\text { TIr4 } \\
M \times 1\end{array}$ & $\begin{array}{l}\text { Patarca et al. } 1989 \\
\text { Poltorak et al. } 1998 \text {; Qureshi et al. } 1999 \\
\text { Staeheli et al. } 1986\end{array}$ \\
\hline
\end{tabular}

aThe chromosomal map position or gene name is provided, if known. (N.D.) Not determined.

${ }^{\mathrm{b}}$ S/c11 al alleles have an effect on mouse susceptibility to visceral Leishmaniasis pathogens, and to Salmonella typhimurium.

'In addition to the genetic linkages cited here, other work has demonstrated that an additional locus for susceptibility to Listeria resides on chromosome 2, and it has been suggested that polymorphisms in the C5 complement gene account for differences in susceptibility (Gervais et al. 1984).

dMouse malaria is caused by Plasmodium chabaudi infection. Although $P$. chabaudi is not a human pathogen, it has many features of pathogenesis that resemble human malarias (Taylor-Robinson 1995).

eSusceptibility to scrub typhus has been mapped to chromosome 5, and it has been suggested that polymorphisms in the Etal gene account for differences in susceptibility.

tious diseases will lead to the identification of several more infection susceptibility genes in the near future.

Although it may be possible to design mutagenesis screens for infection phenotypes (de Angelis et al. 2000; Flaswinkel et al. 2000; Nolan et al. 2000), the data in Table 1 suggests that naturally occurring variation in mouse infectious disease susceptibility is already a very useful resource for finding important infection susceptibility genes. Historically, many pathogens have been studied in mice, and there is a large published body of data that may contain further information on genetic variation in susceptibility. Even in the absence of such clues, simple screens of existing mouse strains for variation in infectious disease-related phenotypes can be easily performed. In parallel, screens of inbred mouse strains that segregate the genomes of two parental inbred mouse strains [e.g., recombinant inbred strains, recombinant congenic strains, and chromosome substitution strains (Justice et al. 1992; Nadeau et al. 2000) offer a different way of uncovering genetic variation in disease susceptibility, even if the parental stocks show no difference in phenotype (P. Demant, pers. comm.). This is because disease susceptibility is often affected by alleles at multiple genes that can have complex epistatic interactions, and the segregation of parental genomes sometimes reveals the existence of genetic differences that cannot be appreciated through analysis of the parental strains.
The different evolutionary histories of mice and humans make genetic studies of mice particularly valuable as a complement to human genetic studies of susceptibility to infection. Mice are very likely to have numerous genetic polymorphisms in functions that do not commonly vary in human populations. By chance alone, an important host susceptibility gene could be polymorphic in mice, but rarely, if ever, polymorphic in humans. More ominously, there could be a lack of polymorphism in an important host susceptibility gene in either mouse or human because of the differential selective effects of the infectious diseases important in the history of the mouse and human populations. An illustration of the power of infectious disease as a selective force is provided by the high prevalence of apparently deleterious hemoglobin alleles among humans living in regions where malaria infection is extremely common (for review, see Weatherall et al. 1997). For these reasons, it is vital to scan for useful genetic polymorphisms in more than one mammalian host, to minimize the chance that a molecule that may be a key target of therapeutic intervention goes undiscovered.

\section{ACKNOWLEDGMENTS}

I thank Rebecca Mosher, Victor Boyartchuk, James Watters, Fred Winston, Igor Kramnik, Jon Seidman, Susan Dymecki, Ralph Isberg, Nancy Andrews, and anonymous reviewers for their helpful suggestions and comments on various drafts of this manuscript. 


\section{REFERENCES}

Abel, L. and Dessein, A.J. 1998. Genetic epidemiology of infectious diseases in humans: Design of population-based studies. Emerg. Infect. Dis. 4: 593-603.

Abel, L., Sanchez, F.O., Oberti, J., Thuc, N.V., Van Hoa, L., Lap, V.D., Skamene, E., Lagrange, P.H., and Schurr, E. 1998. Susceptibility to leprosy is linked to the human NRAMP1 gene. J. Infect. Dis. 177: 133-145.

Altare, F., Jouanguy, E., Lamhamedi, S., Doffinger, R., Fischer, A., and Casanova, J.L. 1998. Mendelian susceptibility to mycobacterial infection in man. Curr. Opin. Immunol. 10: 413-417.

Anthony, L.S., Skamene, E., and Kongshavn, P.A. 1988. Influence of genetic background on host resistance to experimental murine tularemia. Infect. Immun. 56: 2089-2093.

Beckers, M.C., Yoshida, S., Morgan, K., Skamene, E., and Gros, P. 1995. Natural resistance to infection with Legionella pneumophila: Chromosomal localization of the Lgn1 susceptibility gene. Mamm. Genome 6: 540-545.

Beebe, A.M., Mauze, S., Schork, N.J., and Coffman, R.L. 1997. Serial backcross mapping of multiple loci associated with resistance to Leishmania major in mice. Immunity 6: 551-557.

Bellamy, R. 1998. Genetic susceptibility to tuberculosis in human populations. Thorax 53: 588-593.

- 2000. Identifying genetic susceptibility factors for tuberculosis in Africans: A combined approach using a candidate gene study and a genome-wide screen. Clin. Sci. 98: 245-250.

Bellamy, R., Ruwende, C., Corrah, T., McAdam, K.P.W.J, Whittle, H.C., and Hill, A.V.S. 1998. Variations in the NRAMP1 gene and susceptibility to tuberculosis in west Africans. New Engl. J. Med. 338: 640-644.

Bellamy, R., Beyers, N., McAdam, K.P.W.J., Ruwende, C., Gie, R., Samaai, P., Bester, D., Meyer, M., Corrah, T., Collin, M., et al. 2000. Genetic susceptibility to tuberculosis in Africans: A genome-wide scan. Proc. Natl. Acad. Sci. 97: 8005-8009.

Bernstein, M.S. and Locksley, R.M. 1991. Legionella infections. In Harrison's Principles of Internal Medicine, 12th ed. (eds. Wilson et al.), pp. 634-637. McGraw-Hill, New York.

Boyartchuk, V., Broman, K.W., Mosher, R.E., D’Orazio, S., Starbach, M., and Dietrich, W.F. Multigenic control of Listeria monocyotgenes susceptibility in mice. Nat. Genet. (in press)

Burt, R.A., Baldwin, T.M., Marshall, V.M. and Foote, S.J. 1999. Temporal expression of an H2-linked locus in host response to mouse malaria. Immunogenetics 50: 278-285.

Ciancotto, N., Eisenstein, B.I., Engleberg, N.C., and Shuman, H. 1989. Genetics and molecular pathogenesis of Legionella pneumophila, an intracellular parasite of macrophages. Mol. Biol. Med. 6: 409-424.

Cooper, A.M., Dalton, D.K., Stewart, T.A., Griffin, J.P., Russell, D.G., and Orme, I.M. 1993. Disseminated tuberculosis in interferon gamma gene-disrupted mice. J. Exp. Med. 178: 2243-2247.

Cooper, A.M., Magram, J., Ferrante, J., and Orme, I.M. 1997. Interleukin 12 (IL-12) is crucial to the development of protective immunity in mice intravenously infected with mycobacterium tuberculosis. J. Exp. Med. 186: 39-45.

Cooper, A.M., Segal, B.H., Frank, A.A., Holland, S.M., and Orme, I.M. 2000. Transient loss of resistance to pulmonary tuberculosis in p47(phox $\left.{ }^{-1-}\right)$ mice. Infect. Immun. 68: 1231-1234.

Curie, C., Alonso, J.M., Le Jean, M., Ecker, J.R., and Briat, J.F. 2000. Involvement of NRAMP1 from Arabidopsis thaliana in iron transport. Biochem. J. 347: 749-755.

Dalton, D.K., Pitts-Meek, S., Keshav, S., Figari, I.S., Bradley, A., and Stewart, T.A. 1993. Multiple defects of immune cell function in mice with disrupted interferon-gamma genes. Science 259: $1739-1742$.

de Angelis, M.H., Flaswinkel, H., Fuchs, H., Rathkolb, B., Soewarto, D., Marschall, S., Heffner, S., Pargent, W., Wuensch, K., Jung, M., et al. 2000. Genome-wide, large-scale production of mutant mice by ENU mutagenesis. Nat. Genet. 25: 444-447.

Deveraux, Q.L. and Reed, J.C. 1999. IAP family proteins-suppressors of apoptosis. Genes \& Dev. 13: 239-252.
Dietrich, W.F., Damron, D.M., Isberg, R.R., Lander, E.S., and Swanson, M.S. 1995. Lgn1, a gene that determines susceptibility to Legionella pneumophila, maps to mouse chromosome 13 Genomics 26: 443-450.

Diez, E., Yaraghi, Z., MacKenzie, A., and Gros, P. 2000. The neuronal apoptosis inhibitory protein (Naip) is expressed in macrophages and is modulated after phagocytosis and during intracellular infection with Legionella pneumophila. J. Immunol. 164: $1470-1477$.

D'Souza, J., Cheah, P.Y., Gros, P., Chia, W., and Rodrigues, V. 1999 Functional complementation of the malvolio mutation in the taste pathway of Drosophila melanogaster by the human natural resistance-associated macrophage protein 1 (Nramp-1). J. Exp. Biol. 202: 1909-1915.

Ehlers, S., Benini, J., Kutsch, S., Endres, R., Rietschel, E.T., and Pfeffer, K. 1999. Fatal granuloma necrosis without exacerbated mycobacterial growth in tumor necrosis factor receptor p55 gene-deficient mice intravenously infected with Mycobacterium avium. Infect. Immun. 67: 3571-3579.

Ehlers, S., Kutsch, S., Ehlers, E.M., Benini, J., and Pfeffer, K. 2000. Lethal granuloma disintegration in mycobacteria-infected TNFRp55 $5^{-/-}$mice is dependent on T cells and IL-12. J. Immunol. 165: $483-492$.

Endrizzi, M.G., Hadinoto, V., Growney, J.D., Miller, W., and Dietrich, W.F. 2000. Genomic sequence analysis of the mouse Naip gene array. Genome Res. 10: 1095-1102.

Fang, G.D., Fine, M., Orloff, J., Arisumi, D., Yu, V.L., Kapoor, W., Grayston, J.T., Wang, S.P., Kohler, R., Muder, R.R., et al. 1990. New and emerging etiologies for community-acquired pneumonia with implications for therapy: a prospective multicenter study of 359 cases. Medicine 69: 307-316.

Flaswinkel, H., Alessandrini, F., Rathkolb, B., Decker, T., Kremmer, E., Servatius, A., Jakob, T., Soewarto, D., Marschall, S., Fella, C., et al. 2000. Identification of immunological relevant phenotypes in ENU mutagenized mice. Mamm. Genome 11: 526-527.

Fleming, M.D., Trenor, 3rd, C.C., Su, M.A., Foernzler, D., Beier, D.R., Dietrich, W.F., and Andrews, N.C. 1997. Microcytic anaemia mice have a mutation in Nramp2, a candidate iron transporter gene. Nat. Genet. 16: 383-386.

Flynn, J.L., Goldstein, M.M., Triebold, K.J., Koller, B., and Bloom, B.R. 1992. Major histocompatibility complex class I-restricted T cells are required for resistance to Mycobacterium tuberculosis infection. Proc. Natl. Acad. Sci. 89: 12013-12017.

Flynn, J.L., Chan, J., Triebold, K.J., Dalton, D.K., Stewart, T.A., and Bloom, B.R. 1993. An essential role for interferon gamma in resistance to Mycobacterium tuberculosis infection. J. Exp, Med. 178: $2249-2254$

Flynn, J.L., Goldstein, M.M., Chan, J., Triebold, K.J., Pfeffer, K., Lowenstein, C.J., Schreiber, R., Mak, T.W., and Bloom, B.R. 1995. Tumor necrosis factor-alpha is required in the protective immune response against Mycobacterium tuberculosis in mice. Immunity 2: 561-572.

Foote, S.J., Burt, R.A., Baldwin, T.M., Presente, A., Roberts, A.W., Laurel, Y.L, Lew, A.M., and Marshall, V.M. 1997. Mouse loci for malaria-induced mortality and the control of parasitaemia. Nat. Genet. 17: 380-381.

Fortin, A., Belouchi, A., Tam, M.F., Cardon, L., Skamene, E., Stevenson, M.M., and Gros, P. 1997. Genetic control of blood parasitaemia in mouse malaria maps to chromosome 8 . Nat. Genet. 17: 382-383.

Gao, L.Y. and Abu Kwaik, Y. 1999. Apoptosis in macrophages and alveolar epithelial cells during early stages of infection by Legionella pneumophila and its role in cytopathogenicity. Infect. Immun. 67: 862-870.

Gervais, F., Stevenson, M., and Skamene, E. 1984. Genetic control of resistance to Listeria monocytogenes: Regulation of leukocyte inflammatory responses by the Hc locus. J. Immunol. 132: $2078-2083$.

Govoni, G., Gauthier, S., Billia, F., Iscove, N.N., and Gros, P. 1997. Cell-specific and inducible Nramp1 gene expression in mouse macrophages in vitro and in vivo. J. Leukoc. Biol. 62: 277-286. 
Greenwood, C.M.T., Fujiwara, T.M., Boothroyd, L.J., Miller, M.A., Frappier, D., Fanning, E.A., Schurr, E., and Morgan, K. 2000. Linkage of tuberculosis to chromosome 2q35 loci, including NRAMP1, in a large aboriginal Canadian family. Am. J. Hum. Genet. 67: 405-416.

Growney, J.D. and Dietrich, W.F. 2000. High-resolution genetic and physical map of the Lgn1 interval in C57BL/6J implicates Naip2 or Naip5 in Legionella pneumophila pathogenesis. Genome Res. 10: $1158-1171$

Growney, J.D., Scharf, J.M., Kunkel, L.M., and Dietrich, W.F. 2000 Evolutionary divergence of the mouse and human Lgn1/SMA repeat structures. Genomics 64: 62-81.

Gruenheid, S. and Gros, P. 2000. Genetic susceptibility to intracellular infections: Nramp1, macrophage function and divalent cations transport. Curr. Opin. Microbiol. 3: 43-48.

Gruenheid S., Pinner, E., Desjardins, M., and Gros, P. 1997. Natural resistance to infection with intracellular pathogens: The Nramp1 protein is recruited to the membrane of the phagosome. J. Exp. Med. 185: 717-730.

Gunshin, H., Mackenzie, B., Berger, U.V., Gunshin, Y., Romero, M.F., Boron, W.F., Nussberger, S., Gollan, J.L., and Hediger, M.A. 1997. Cloning and characterization of a mammalian proton-coupled metal-ion transporter. Nature 388: 482-488.

Hill, A.V.S. 1998. The immunogenetics of human infectious diseases Annu. Rev. Immunol. 16: 593-617.

Holcik, M., Thompson, C.S., Yaraghi, Z., Lefebvre, C.A., MacKenzie, A.E., and Korneluk, R.G. 2000. The hippocampal neurons of neuronal apoptosis inhibitory protein 1 (NAIP1)-deleted mice display increased vulnerability to kainic acid-induced injury. Proc. Natl. Acad. Sci. 97: 2286-2290.

Huang, S., Scharf, J., Growney, J.D., Endrizzi, M.G., and Dietrich, W.F. 1999. The mouse Naip gene cluster on Chromosome 13 encodes several distinct functional transcripts. Mamm. Genome 10: $1032-1035$

Jouanguy, E., Doffinger, R., Dupuis, S., Pallier, A., Altare, F., and Casanova, J.L. 1999a. IL-12 and IFN-g in host defense against mycobacteria and salmonella in mice and men. Curr. Opin. Immunol. 11: 346-351.

Jouanguy, E., Lamhamedi-Cheraddi, S., Lammas, D., Dorman, S.E., Fondaneche, M.C., Dupuis, S., Doffinger, R., Altare, F., Girdlestone, J., Emile, J.F., et al. 1999b. A human IFNGR1 small deletion hotspot associated with dominant susceptibility to mycobacterial infection. Nat. Genet. 21: 370-378.

Justice M.J., Jenkins, N.A., and Copeland, N.G. 1992. Recombinant inbred mouse strains: Models for disease study. Trends Biotechnol. 10: $120-126$.

Kehres, D.G., Zaharik, M.L., Finlay, B.B., and Maguire, M.E. 2000. The NRAMP proteins of Salmonella typhimurium and Escherichia coli are selective manganese transporters involved in the response to reactive oxygen. Mol. Microbiol. 36: 1085-1100.

Kemp, S.J., Iraqi, F., Darvasi, A., Soller, M., and Teale, A.J. 1997. Localization of genes controlling resistance to trypanosomiasis in mice. Nat. Genet. 16: 194-196.

Kramnik, I., Dietrich, W.F., Demant, P., and Bloom, B.R. 2000. Genetic control of resistance to experimental infection with virulent Mycobacterium tuberculosis. Proc. Natl. Acad. Sci. 97: 8560-8565.

Kruglyak, L. 1999. Prospects for whole-genome linkage disequilibrium mapping of common disease genes. Nat. Genet. 22: 139-144.

Lavebratt, C., Apt, A.S., Nikonenko, B.V., Schalling, M., and Schurr, E. 1999. Severity of tuberculosis in mice is linked to distal chromosome 3 and proximal chromosome 9. J. Inf. Dis. 180: $150-155$.

Lefebvre, S., Burglen, L., Reboullet, S., Clermont, O., Burlet, P., Viollet, L., Benichou, B., Cruaud, C., Millasseau, P., Zeviani, M., et al. 1995. Identification and characterization of a spinal muscular atrophy-determining gene. Cell 80: 155-165.

Lipoldova, M., Svobodova, M., Krulova, M., Havelkova, H., Badalova, J., Nohynkova, E., Holan, V., Hart, A.A.M., Volf, P., and Demant, P. 2000. Susceptibility to Leishmania major infection in mice:
Multiple loci and heterogeneity of immunopathological phenotypes. Genes Immun. 1: 200-206.

Liston, P., Roy, N., Tamai, K., Lefebvre, C., Baird, S., Cherton-Horvat, G., Farahani, R., McLean, M., Ikeda, J.E., MacKenzie, A., and Korneluk, R.G. 1996. Suppression of apoptosis in mammalian cells by NAIP and a related family of IAP genes. Nature 379: 349-353.

MacMicking, J.D., North, R.J., LaCourse, R., Mudgett, J.S., Shah, S.K., and Nathan, C.F. 1997. Identification of nitric oxide synthase as a protective locus against tuberculosis. Proc. Natl. Acad. Sci. 94: $5243-5248$

Makui, H., Roig, E., Cole, S.T., Helmann, J.D., Gros, P., and Cellier, M.F.M. 2000. Identification of the Escherichia coli K-12 Nramp orthologue $(\mathrm{MntH})$ as a selective divalent metal ion transporter. Mol. Microbiol. 35: 1065-1078.

Malo, D. and Skamene, E. 1994. Genetic control of host resistance to infection. Trends Genet. 10: 365-371.

Marra, A. and Shuman, H.A. 1992. Genetics of Legionella pneumophila virulence. Annu. Rev. Genet. 26: 51-69.

Mercer, E.A., Korhonen, L., Skoglosa, Y., Olsson, P.A, Kukkonen, J.P, and Lindholm, D. 2000. NAIP interacts with hippocalcin and protects neurons against calcium-induced cell death through caspase-3-dependent and -independent pathways. EMBO J. 19: $3597-3607$.

Miller, L.K. 1999. An exegesis of IAPs: Salvation and surprises from BIR motifs. Trends Cell Biol. 9: 323-328.

Nadeau, J.H., Singer, J.B., Matin, A,. and Lander, E.S. 2000. Analysing complex genetic traits with chromosome substitution strains. Nat. Genet. 24: 221-225.

Nolan, P.M., Peters, J., Strivens, M., Rogers, D., Hagan, J., Spurr, N., Gray, I.C., Vizor, L., Brooker, D., Whitehill, E., et al. 2000. A systematic, genome-wide, phenotype-driven mutagenesis programme for gene function studies in the mouse. Nat. Genet. 25: $440-443$.

North, R.J., LaCourse, R., Ryan, L., and Gros, P. 1999. Consequence of Nramp1 deletion to Mycobacterium tuberculosis infection in mice. Infect. Immun. 67: 5811-5814.

Patarca, R., Freeman, G.J., Singh, R.P., Wei, F.Y., Durfee, T., Blattner, F., Regnier, D.C., Kozak, C.A., Mock, B.A., Morse, III, H.C., Jerrells, T.R., and Cantor, H. 1989. Structural and functional studies of the Early T Lymphocyte Activation 1 (Eta-1) gene. J. Exp. Med. 170: 145-161.

Poltorak, A., He, X., Smirnova, I., Liu, M.Y., Huffel, C.V., Du, X., Birdwell, D., Alejos, E., Silva, M., Galanos, C., et al. 1998. Defective LPS signaling in C3H/HeJ and C57BL/10ScCr mice: Mutations in Tlr4 gene. Science 282: 2085-2088.

Qureshi, S.T., Lariviere, L., Leveque, G., Clermont, S., Moore, K.J., Gros, P., and Malo, D. 1999. Endotoxin-tolerant mice have mutations in Toll-like receptor 4 (Tlr4). J. Exp. Med. 189: 615-625.

Risch, N. and Merikangas, K. 1996. The future of genetic studies of complex human diseases. Science 273: 1516-1517.

Roberts, J.E., Watters, J.W., Ballard, J.D., and Dietrich, W.F. 1998. Ltx1, a mouse locus that influences the susceptibility of macrophages to cytolysis caused by intoxication with Bacillus anthracis lethal factor, maps to chromosome 11. Mol. Microbiol. 29: 581-591.

Roberts, L.J., Baldwin, T.M., Curtis, J.M., Handman, E., and Foote, S.J. 1997. Resistance to Leishmania major is linked to the $\mathrm{H} 2$ region on chromosome 17 and to chromosome 9. J. Exp. Med. 185: $1705-1710$.

Roberts, L.J., Baldwin, T.M., Speed, T.P., Handman, E., and Foote, S.J. 1999. Chromosomes X, 9, and the H2 locus interact epistatically to control Leishmania major infection. Eur. J. Immunol. 29: 3047-3050.

Roy, N., Mahadevan, M.S., McLean, M., Shutler, G., Yaraghi, Z., Farahani, R., Baird, S., Besner-Johnston, A., Lefebvre, C., Kang, X., et al. 1995. The gene for neuronal apoptosis inhibitory protein is partially deleted in individuals with spinal muscular atrophy. Cell 80: 167-178.

Sampson, I.A. 1988. Prevalence of antibody to Legionella pneumophila

\section{Genome Research}


in Aborigines and non-Aborigines in Western Australia. Med. J. Austr. 148: 16-19.

Scalzo, A.A., Fitzgerald, N.A., Simmons, A., La Vista, A.B., and Shellam, G.R. 1990. Cmv-1, a genetic locus that controls murine cytomegalovirus replication in the spleen. J. Exp. Med. 171: $1469-1483$.

Scharf, J.M., Damron, D., Frisella, A., Bruno, S., Beggs, A. H., Kunkel, L.M. and Dietrich, W.F.1996. The mouse region syntenic for human spinal muscular atrophy lies within the Lgn1 critical interval and contains multiple copies of Naip exon 5. Genomics 38: $405-417$.

Sebastiani, G., Olien, L., Gauthier, S., Skamene, E., Morgan, K., Gros, P., and Malo, D. 1998. Mapping of genetic modulators of natural resistance to infection with Salmonella typhimurium in wild-derived mice. Genomics 47: 180-186.

Shaw, M.A., Collins, A., Peacock, C.S., Miller, E.N., Black, G.F., Sibthorpe, D., Lins-Lainson, Z., Shaw, J.J., Ramos, F., Silveira, F., and Blackwell, J.M. 1997. Evidence that genetic susceptibility to Mycobacterium tuberculosis in a Brazilian population is under oligogenic control: Linkage study of the candidate genes NRAMP1 and TNFA. Tubercle Lung Dis. 78: 35-45.

The SNP Consortium Ltd., http://snp.cshl.org/

Speliotes, E.K., Uren, A., Vaux, D., and Horvitz, H.R. 2000. The survivin-like C. elegans BIR-1 protein acts with the Aurora-like kinase AIR-2 to affect chromosomes and the spindle midzone. Mol. Cell 6: 211-223.

Stach, J.L., Gros, P., Forget, A., and Skamene, E. 1984. Phenotypic expression of genetically-controlled natural resistance to Mycobacterium bovis (BCG). J. Immunol. 132: 888-892.

Staeheli, P., Haller, O., Boll, W., Lindenmann, J., and Weissmann, C. 1986. Mx protein: Constitutive expression in 3T3 cells transformed with cloned Mx cDNA confers selective resistance to influenza virus. Cell 44: $147-158$.

Sugawara, I., Yamada, H., Kaneko, H., Mizuno, S., Takeda, K., and Akira, S. 1999. Role of interleukin-18 (IL-18) in mycobacterial infection in IL-18-gene-disrupted mice. Infect. Immun. 67: 2585-2589.

Taylor-Robinson, A.W. 1995. Regulation of immunity to malaria: Valuable lessons learned from murine models. Parasit. Today 11: $334-342$.

Thomine, S., Wang, R., Ward, J.M., Crawford, N.M, and Schroeder, J.I. 2000. Cadmium and iron transport by members of a plant metal transporter family in Arabidopsis with homology to Nramp genes. Proc. Natl. Acad. Sci. 97: 4991-4996.

Trischmann, T.M. 1984. Single locus in BXH-2 mice responsible for inability to control early proliferation of Trypanosoma cruzi. Infect. Immun. 46: 658-662.

Vidal, S., Tremblay, M.L, Govoni, G., Gauthier, S., Sebastiani, G., Malo, D., Skamene, E., Olivier, M., Jothy, S., and Gros, P. 1995. The Ity/Lsh/Bcg locus: Natural resistance to infection with intracellular parasites is abrogated by disruption of the Nramp1 gene. J. Exp. Med. 182: 655-666.

Vidal, S.M., Malo, D., Vogan, K., Skamene, E., and Gros, P. 1993. Natural resistance to infection with intracellular parasites: isolation of a candidate for Bcg. Cell 73: 469-485.

Vidal, S.M., Pinner, E.,Lepage, P., Gauthier, S., and Gros, P. 1996. Natural resistance to intracellular infections: Nramp1 encodes a membrane phosphoglycoprotein absent in macrophages from susceptible (Nramp1 D169) mouse strains. J. Immunol. 157: 3559-3568.

Vogel, J.P. and Isberg, R.R. 1999. Cell biology of Legionella pneumophila. Curr. Opin. Microbiol. 2: 30-34.

Weatherall, D., Clegg, J., and Kwiatkowski, D. 1997. The role of genomics in studying genetic susceptibility to infectious disease. Genome Res. 7: 967-973.

Weinrauch, Y. and Zychlinsky, A. 1999. The induction of apoptosis by bacterial pathogens. Annu. Rev. Microbiol. 53: 155-187.

Winans, S.C., Burns, D.L., and Christie. P.J. 1996. Adaptation of a conjugal transfer system for the export of pathogenic macromolecules. Trends Microbiol. 4: 64-68.

World Health Report. 1999. http://www.who.int/home.info.html. Wunderlich, F., Mossmann, H., Helwig, M., and Schillinger, G. 1988. Resistance to Plasmodium chabaudi in B10 mice: Influence of the H-2 complex and testosterone. Infect. Immun. 56: 2400-2406.

Yamamoto, Y., Klein, T.W., Newton, C.A., Widen, R., and Friedman, H. 1988. Growth of Legionella pneumophila in thioglycollateelicited peritoneal macrophages from $\mathrm{A} / \mathrm{J}$ mice. Infect. Immun. 56: $370-375$.

Yamamoto, Y., Klein, T.W., and Friedman, H. 1991. Legionella pneumophila growth in macrophages from susceptible mice is genetically controlled. Proc. Exp. Biol. Med. 196: 405-409.

Yamamoto, Y., Klein, T.W., Brown, K., and Friedman, H. 1992. Differential morphologic and metabolic alterations in permissive versus nonpermissive murine macrophages infected with Legionella pneumophila. Infect. Immun. 60: 3231-3237.

Yoshida, S.I., Goto, Y., Mizuguchi, Y., Nomoto, K., and Skamene, E. 1991. Genetic control of natural resistance in mouse macrophages regulating intracellular Legionella pneumophila multiplication in vitro. Infect. Immun. 59: 428-432. 


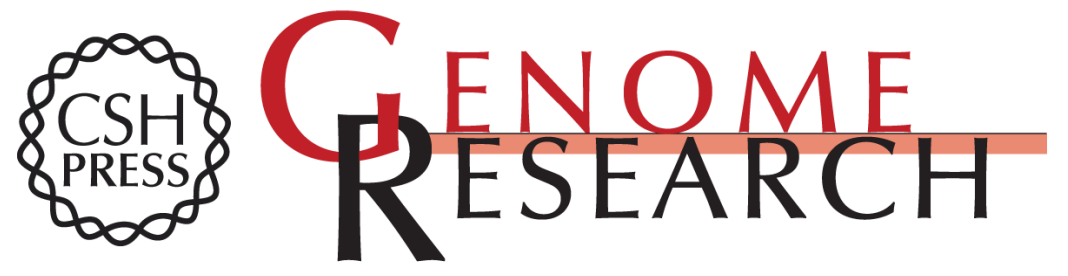

\section{Using Mouse Genetics to Understand Infectious Disease Pathogenesis}

William F. Dietrich

Genome Res. 2001 11: 325-331

Access the most recent version at doi:10.1101/gr.173101

References This article cites 95 articles, 41 of which can be accessed free at:

http://genome.cshlp.org/content/11/3/325.full.html\#ref-list-1

\section{License}

Email Alerting Receive free email alerts when new articles cite this article - sign up in the box at the Service top right corner of the article or click here.

\section{Affordable, Accurate Sequencing.}

To subscribe to Genome Research go to:

https://genome.cshlp.org/subscriptions 